\title{
Management of Upper Airway Infantile Hemangiomas: Experience of One Italian Multidisciplinary Center
}

\author{
Marialuisa Corbeddu ${ }^{1 *}$, Duino Meucci ${ }^{2}$, Andrea Diociaiuti ${ }^{1}$, Simona Giancristoforo ${ }^{1}$, \\ Roberta Rotunno ${ }^{1}$, Michaela Veronika Gonfiantini ${ }^{3}$, Marilena Trozzi ${ }^{2}$, Sergio Bottero ${ }^{2}$ and \\ May El Hachem ${ }^{1}$
}

1 Dermatology Unit and Genodermatosis Unit, Genetics and Rare Diseases Research Division, Bambino Gesù Children's Hospital, IRCCS, Rome, Italy, ${ }^{2}$ Airway Surgery Unit, Bambino Gesù Children's Hospital, IRCCS, Rome, Italy, ${ }^{3}$ Rare Diseases and Genetic Unit, Bambino Gesù Children's Hospital, IRCCS, Rome, Italy

OPEN ACCESS

Edited by:

Judie Arulappan,

Sultan Qaboos University, Oman

Reviewed by:

Shinji Kagami,

Kanto Central Hospital of the Mutual

Aid Association of Public School

Teachers, Japan

Anne Dompmartin,

Centre Hospitalier Universitaire de

Caen, France

*Correspondence:

Marialuisa Corbeddu

marialuisa.corbeddu@gmail.com

Specialty section:

This article was submitted to

Children and Health,

a section of the journal

Frontiers in Pediatrics

Received: 30 May 2021

Accepted: 02 November 2021

Published: 07 December 2021

Citation:

Corbeddu M, Meucci D, Diociaiuti A

Giancristoforo S, Rotunno R,

Gonfiantini MV, Trozzi M, Bottero S

and El Hachem M (2021)

Management of Upper Airway Infantile

Hemangiomas: Experience of One

Italian Multidisciplinary Center.

Front. Pediatr. 9:717232.

doi: 10.3389/fped.2021.717232
Airway infantile hemangiomas (IHs) can represent a life-threatening condition since the first months of life. They may be isolated or associated to cutaneous IHs, and/or part of PHACES syndrome. Diagnosis, staging, and indication to treatment are not standardized yet despite the presence in the literature of previous case series and reviews. The diagnosis might be misleading, especially in the absence of cutaneous lesions. Airway endoscopy is the gold standard both for diagnosis and follow-up since it allows evaluation of precise localization and entity of obstruction and/or stricture. Proliferation of $\mathrm{IH}$ in the infant airways manifests frequently with stridor and treatment is required as soon as possible to prevent further complications. The first line of therapy is oral propranolol, but duration of treatment is not yet well-defined. All considered, we report the experience of our multidisciplinary center from 2009 to date, on 36 patients affected by airway $\mathrm{Hs}$, and successfully treated with oral propranolol. Thus, the authors propose their experience for the management of airway IHs, specifically early diagnosis, when to perform endoscopy, how to interpret its findings, and when to stop the treatment.

Keywords: airway, infantile hemangioma (IH), endoscopy, stridor, propranolol

\section{INTRODUCTION}

Infantile hemangiomas (IHs) are the most common benign vascular tumors in children and are a neoplastic proliferation of endothelial cells. They are characterized by a growth phase that consists in a rapid proliferation of blood vessels in the first months of life. Afterward, a spontaneous gradual involution, partial or complete, with or without scarring and in some cases with a residual fibrofatty tissue, usually continues until 5-7 years of age. They are benign and self-limited, but sometimes they can manifest complications such as ulceration, permanent disfigurement, and they may compromise vital organs causing functional and life-threatening damages (1). Most IHs are not clinically evident at birth and sometimes they may be preceded by a cutaneous mark, more frequently an area of pallor at the hemangioma site. Airway IHs (AIHs) constitute a rare occurrence with an unknown incidence. They may be associated with cutaneous IH with a particular distribution in 50\% of cases, called "beard" area or S3 area, according to Haggstrom and Frieden's classification (2). This distribution includes the preauricular skin, mandible, lower lip, chin, and/or anterior neck. However, they can also develop in children in the absence of cutaneous hemangiomas. Moreover, recent studies demonstrated that AIHs might be associated with more limited skin patterns, as well as with posterior and lateral neck involvement (3). 
PHACES syndrome is characterized by posterior fossa anomalies, IH, aortic, cardiac, and eye malformations, and sternal defect. Several studies reported its association with AIHs with variable percentages (16-50\%) (4-6). AIHs usually involve the subglottis, which is the narrowest part of the pediatric airway and are mostly located in its left posterolateral part $(7,8)$. The infants manifest frequently progressive hoarseness or biphasic stridor, especially between the age of 6 and 12 weeks, with a possible evolution to respiratory failure. Respiratory distress is caused by external compression or IH localization within an airway tract that could cause a partial or total obstruction. Other symptoms include cough, sleep apnea, and failure to thrive. Symptoms are often mistaken as infectious or inflammatory croup, bronchiolitis, laryngitis, allergy, tracheomalacia, or tumor (9).

Differential diagnosis is based on the peculiar characteristics of stridor associated with AIHs, which is usually biphasic and worsen despite non-specific treatments. Furthermore, time of onset of respiratory symptoms is typical and differs from other congenital airway diseases, in fact it is generally absent at birth and usually develops at $2-4$ months of age (10). In a child with noisy breathing, stridor, or respiratory distress a complete endoscopic evaluation is crucial and early intervention is mandatory to prevent life-threatening complications.

The first step is to perform an awake trans-nasal fiberoptic laryngoscopy to evaluate laryngeal motility and pharyngolaryngeal functional aspects. The assessment of the upper and lower airways is completed with an asleep endoscopy, performed under anesthesia while maintaining spontaneous breathing, using sevoflurane or intravenous propofol. The occurrence of laryngospasm passing the glottis with the endoscope, could be prevented by using laryngeal local anesthesia. Usually, in our experience, a 3.5-mm video-bronchoscope, passed through the nose, is used in infants, while a $2.2-\mathrm{mm}$ slim fiber-optic bronchoscope in newborns. In case of suspected subglottic or tracheal stenosis, a direct laryngo-tracheoscopy by rigid endoscope is indicated to obtain a clear view of the subglottis and the trachea. Endoscopy is usually performed using a $4 \mathrm{~mm}$ diameter rigid fiber-optic or $2 \mathrm{~mm}$, based on patient age or size of the stenotic tract. This procedure grants the identification of the AIH, its location, extent, and degree of obstruction. The endoscopic features of $\mathrm{AIH}$ are very characteristic. It usually appears as a red-violet mass, with a smooth and regular surface, easily compressible. When the IH involves the subglottic space, measurement of the degree of stenosis, and percentage of obstruction is achieved passing endotracheal tubes of different sizes through the stricture, then comparing results with the expected airway size for age (11).

Therapeutic options before the introduction of oral propranolol included tracheotomy, $\mathrm{CO}_{2}$ laser, systemic or intralesional corticosteroids, and/or open surgical excision. Oral propranolol is now considered the mainstay of treatment, since it is safe, manageable, and effective. However, there is a lack of specific guidelines in this localization of $\mathrm{IH}$, about initiation, dosage, and duration of treatment. A longer therapy course for $\mathrm{AIH}$ is reported in the literature, compared to their cutaneous counterpart, as described by Elluru et al., with a median duration of 15 months (range 7-34 months). In addition, the age at the end of treatment is debated, thus some authors suggest to continue propranolol at least until 15-18 months of age (12).

We present a case series of 36 patients with airway involvement successfully treated with oral propranolol and discuss our multidisciplinary management.

\section{CLINICAL OBSERVATIONS}

Demographics and clinical data from 36 patients were collected (Table 1). Twenty-seven out of 36 children (75\%) were girls, $22.2 \%(8 / 36)$ had risk factors, including prematurity, twin birth, cesarean section, gestational diabetes, pre-eclampsia, and intrauterine fetal distress. Cutaneous distribution included beard area, but also tragus, sternum, helix, tongue, parotid, nose, and genitalia. A total of $36.1 \%$ of patients (13/36) had no cutaneous involvement. In our cases series, only two children were affected with PHACES syndrome. Respiratory symptoms were absent in $13.9 \%$ of patients (5/36). Age at onset of cutaneous and/or respiratory symptoms ranged from birth to 90 days of age (average 30.9 and median 30). Therapy was started from 1 to 10 months of age (average 3.5 and median 3) with a total duration ranging from 6 to 26 months (average 15.36 and median 15) and suspension at months 10-54 of age (average 20 and median 19). Additional therapy with steroids was employed in the $27.8 \%$ of patients (10/36). Twenty-eight of the 36 patients were brought to a maintenance dose of $2 \mathrm{mg} / \mathrm{kg} / \mathrm{d}$, whereas seven patients required $3 \mathrm{mg} / \mathrm{kg} / \mathrm{d}$ and 1 with PHACES syndrome had to maintain a dosage of 1 $\mathrm{mg} / \mathrm{kg} / \mathrm{d}$. Five patients $(13.9 \%)$ had relapses at suspension and restarted oral therapy. Endoscopy characteristics were also collected (Table 2). In our series all patients with recurrence of symptoms after the end of the therapy had endoscopic evidence of persistence of the $\mathrm{IH}$, with subglottic obstruction $\geq 30 \%$ (range $30-50 \%$ ). The mean percentage of airway obstruction before treatment was $50.29 \%$ (range 10-80\%) and the mean percentage after treatment was 7\% (range 0-30\%). Furthermore, subglottic IHs had mostly an eccentric localization pattern (64.7\% of cases). In 10 patients we found extra-laryngeal airway localizations of AIHs: pharynx in seven cases and trachea in three patients.

\section{DISCUSSION}

Airway IHs cause functional damage due to upper airway obstruction leading to respiratory insufficiency and lifethreatening complications in the absence of treatment. They are frequently associated with a cutaneous distribution in a known fashion (3). Although, as seen in our case series and in the literature, they can present without cutaneous involvement. There is a lack of guidelines and consensus on diagnosis and treatment that often depend on local experience of dermatologists, ear-nose-throat specialists (ENT), and broncopneumologists. Propranolol is the mainstay of treatment; however, it is still preceded by oral steroid courses especially in non-reference centers. B-blockers are rapidly efficacious, thus, oral steroids treatment should not be administered or 
TABLE 1 | Demographics and clinical data from 36 patients.

\begin{tabular}{|c|c|c|c|c|c|c|c|c|c|c|c|c|}
\hline Case & Sex & Risk factors & Signs & Symptoms & Onset age & $\begin{array}{l}\text { Therapy } \\
\text { start age }\end{array}$ & Dosage & $\begin{array}{l}\text { Therapy end } \\
\text { age }\end{array}$ & $\begin{array}{l}\text { Length of } \\
\text { therapy }\end{array}$ & Relapse & $\begin{array}{l}\text { Other } \\
\text { therapy }\end{array}$ & $\begin{array}{l}\text { Associated } \\
\text { syndromes }\end{array}$ \\
\hline 1 & $\mathrm{~F}$ & None & $\begin{array}{l}\text { Beard distribution, tragus, } \\
\text { helix, tongue, and oral } \\
\text { mucosa }\end{array}$ & None & Birth & $3 \mathrm{mo}$ & $\begin{array}{l}0,5- \\
3 / \mathrm{mg} / \mathrm{kg} / \mathrm{day}\end{array}$ & 22 mo. & $19 \mathrm{mo}$ & No & None & None \\
\hline 2 & $\mathrm{~F}$ & None & None & Yes & $2 \mathrm{mo}$ & $3 \mathrm{mo}$. & $2 \mathrm{mg} / \mathrm{kg} / \mathrm{day}$ & $18 \mathrm{mo}$ & $16 \mathrm{mo}$ & $\begin{array}{l}\text { Yes, at } \\
\text { suspension at } \\
10 \text { mo. of age }\end{array}$ & Steroids & None \\
\hline 3 & M & None & None & Yes & $3 \mathrm{mo}$. & $5 \mathrm{mo}$ & $\begin{array}{l}1.5-2 \\
\mathrm{mg} / \mathrm{kg} / \text { day }\end{array}$ & 22 mo. & $17 \mathrm{mo}$. & No & Steroids & None \\
\hline 4 & M & None & Beard, sternum, tongue & Yes & Birth & $1 \mathrm{mo}$ & $\begin{array}{l}0.5-3 \\
\mathrm{mg} / \mathrm{kg} / \text { day }\end{array}$ & - & - & - & Steroids & None \\
\hline 5 & M & Preterm & Beard, helix, sternum & None & $7 \mathrm{dd}$ & $1 \mathrm{mo}$ & $\begin{array}{l}0.5-1 \\
\mathrm{mg} / \mathrm{kg} / \text { day }\end{array}$ & $18 \mathrm{mo}$ & $17 \mathrm{mo}$ & No & Steroids & PHACES \\
\hline 6 & $\mathrm{~F}$ & None & $\begin{array}{l}\text { Beard, tragus, left parotids, } \\
\text { and thorax }\end{array}$ & Yes & $15 d d$ & $3 \mathrm{mo}$. & $\begin{array}{l}2-3 \\
\mathrm{mg} / \mathrm{kg} / \text { day }\end{array}$ & $26 \mathrm{mo}$ & $16 \mathrm{mo}$. & $\begin{array}{l}\text { Yes, at } \\
\text { suspension at } \\
20 \text { mo. }\end{array}$ & Steroids & None \\
\hline 7 & $\mathrm{~F}$ & None & $\begin{array}{l}\text { Beard tragus, ear, cyrano, } \\
\text { tongue }\end{array}$ & $\begin{array}{l}\text { Otorrhea at } \\
\text { angioma site }\end{array}$ & Birth & $1 \mathrm{mo}$ & $\begin{array}{l}1-3 \\
\mathrm{mg} / \mathrm{kg} / \text { day }\end{array}$ & $26 \mathrm{mo}$. & $25 \mathrm{mo}$. & No & None & None \\
\hline 8 & $\mathrm{~F}$ & None & Right shoulder and axilla & Yes & $1 \mathrm{mo}$ & $3 \mathrm{mo.}$ & $\begin{array}{l}2-3 \\
\mathrm{mg} / \mathrm{kg} / \text { day }\end{array}$ & Still in therapy & Still in therapy & No & None & None \\
\hline 9 & $\mathrm{M}$ & None & $\begin{array}{l}\text { Beard, tragus, lower lip, } \\
\text { mucosal }\end{array}$ & Yes & $15 d d$ & $6 \mathrm{mo}$ & $2 \mathrm{mg} / \mathrm{kg} / \mathrm{day}$ & 19 mo. & $13 \mathrm{mo}$. & No & Steroids & None \\
\hline 10 & $\mathrm{~F}$ & None & $\begin{array}{l}\text { Segmental unilateral in, } \\
\text { neck, mucosal }\end{array}$ & Yes & Birth & $2 \mathrm{mo}$ & $\begin{array}{l}1-2 \\
\mathrm{mg} / \mathrm{kg} / \text { day }\end{array}$ & $19 \mathrm{mo}$. & $17 \mathrm{mo}$. & No & None & None \\
\hline 11 & M & $\begin{array}{l}\text { Preterm, CS, } \\
\text { twin }\end{array}$ & None & Yes & $1 \mathrm{mo}$. & $1 \mathrm{mo}$. & $2 \mathrm{mg} / \mathrm{kg} / \mathrm{day}$ & 20 mo. & $18 \mathrm{mo}$. & $\begin{array}{l}\text { Yes, at } \\
\text { suspension at } \\
13 \text { mo. of age }\end{array}$ & Steroids & None \\
\hline 12 & $\mathrm{~F}$ & None & None & Yes & $1 \mathrm{mo}$. & $7 \mathrm{mo}$. & $\begin{array}{l}1.5-2 \\
\mathrm{mg} / \mathrm{kg} / \text { day }\end{array}$ & 24 mo. & $17 \mathrm{mo}$. & No & Steroids & None \\
\hline 13 & $\mathrm{~F}$ & Preterm & $\begin{array}{l}\text { Temporal and parietal } \\
\text { bilateral, cyrano, lower lip, } \\
\text { oral mucosa, neck }\end{array}$ & None & $3 \mathrm{mo}$. & $3 \mathrm{mo}$. & $\begin{array}{l}0.5-2 \\
\mathrm{mg} / \mathrm{kg} / \mathrm{day}\end{array}$ & 26 mo. & 23 mo. & No & No & $\begin{array}{l}\text { PHACES, } \\
\text { hepatic and } \\
\text { cerebral } \\
\text { hemangiomas }\end{array}$ \\
\hline 14 & $F$ & None & $\begin{array}{l}\text { Segmental unilateral, } \\
\text { preauricular, neck }\end{array}$ & None & Birth & $8 \mathrm{mo.}$ & $2 \mathrm{mg} / \mathrm{kg} / \mathrm{day}$ & $15 \mathrm{mo}$. & $8 \mathrm{mo}$. & No & $\begin{array}{l}\text { Oral steroid } \\
\text { and il, } \\
\text { embolization }\end{array}$ & None \\
\hline 15 & M & None & $\begin{array}{l}\text { Preauricular, ear, beard, oral } \\
\text { mucosa }\end{array}$ & Yes & $1 \mathrm{mo}$. & $4 \mathrm{mo.}$ & $2 \mathrm{mg} / \mathrm{kg} / \mathrm{day}$ & $54 \mathrm{mo.}$ & 26 mo. & $\begin{array}{l}\text { Yes, at } \\
\text { suspension at } \\
20 \text { mo. and } \\
48 \text { mo. of age }\end{array}$ & Steroids & None \\
\hline 16 & $\mathrm{~F}$ & None & Beard, tragus & Yes & Birth & $3 \mathrm{mo}$. & $2 \mathrm{mg} / \mathrm{kg} / \mathrm{day}$ & $13 \mathrm{mo}$. & $10 \mathrm{mo}$. & No & Steroids & None \\
\hline
\end{tabular}


TABLE 1 | Continued

\begin{tabular}{|c|c|c|c|c|c|c|c|c|c|c|c|c|}
\hline Case & Sex & Risk factors & Signs & Symptoms & Onset age & $\begin{array}{l}\text { Therapy } \\
\text { start age }\end{array}$ & Dosage & $\begin{array}{l}\text { Therapy end } \\
\text { age }\end{array}$ & $\begin{array}{l}\text { Length of } \\
\text { therapy }\end{array}$ & Relapse & $\begin{array}{l}\text { Other } \\
\text { therapy }\end{array}$ & $\begin{array}{l}\text { Associated } \\
\text { syndromes }\end{array}$ \\
\hline 17 & $\mathrm{~F}$ & Preterm & $\begin{array}{l}\text { Segmental unilateral right } \\
\text { eye, temporal, parietal, } \\
\text { cyrano, conjunctival }\end{array}$ & Yes & $1 \mathrm{mo}$ & $3 \mathrm{mo}$. & $\begin{array}{l}1-3 \\
\mathrm{mg} / \mathrm{kg} / \mathrm{day}\end{array}$ & $25 \mathrm{mo.}$ & $22 \mathrm{mo.}$ & $\begin{array}{l}\text { Yes, at } \\
\text { suspension at } \\
19 \text { mo. of age }\end{array}$ & Steroids & None \\
\hline 18 & $\mathrm{~F}$ & None & Preauricular bilateral, beard & Yes & $2 \mathrm{mo}$ & $2 \mathrm{mo}$ & $2 \mathrm{mg} / \mathrm{Kg} / \mathrm{day}$ & $10 \mathrm{mo}$. & $8 \mathrm{mo}$. & None & Steroids & None \\
\hline 19 & $\mathrm{~F}$ & None & None & Yes & $2 \mathrm{mo}$ & $4 \mathrm{mo}$ & $\begin{array}{l}2-3 \\
\mathrm{mg} / \mathrm{kg} / \text { day }\end{array}$ & 19 mo. & $15 \mathrm{mo}$ & None & Steroids & None \\
\hline 20 & $\mathrm{~F}$ & CS & Beard, sacral, right leg & None & birth & $2 \mathrm{mo}$ & $2 \mathrm{mg} / \mathrm{Kg} /$ day & $15 \mathrm{mo}$ & $13 \mathrm{mo}$ & None & None & None \\
\hline 21 & $\mathrm{~F}$ & None & Genital & Yes & 2 mo. & $3 \mathrm{mo}$. & 2 mg/kg/day & $18 \mathrm{mo}$. & $15 \mathrm{mo}$. & None & Steroids & None \\
\hline 22 & $\mathrm{~F}$ & CS & $\begin{array}{l}\text { Segmental parietal, } \\
\text { temporal, eye, shoulder left }\end{array}$ & Yes & $1 \mathrm{mo}$ & $1 \mathrm{mo}$ & $\begin{array}{l}1-2 \\
\mathrm{mg} / \mathrm{kg} / \text { day }\end{array}$ & 22 mo. & $21 \mathrm{mo}$. & None & None & None \\
\hline 23 & $\mathrm{~F}$ & None & $\begin{array}{l}\text { Tongue, cheek, preauricular, } \\
\text { lower lip }\end{array}$ & Yes & Birth & $1 \mathrm{mo}$ & $\begin{array}{l}0.5-2 \\
\mathrm{mg} / \mathrm{kg} / \text { day }\end{array}$ & $18 \mathrm{mo}$ & $17 \mathrm{mo}$. & None & None & None \\
\hline 24 & $\mathrm{~F}$ & None & None & Yes & $1 \mathrm{mo}$. & $10 \mathrm{mo}$ & $2 \mathrm{mg} / \mathrm{Kg} /$ day & $24 \mathrm{mo}$. & $14 \mathrm{mo}$. & None & None & None \\
\hline 25 & $\mathrm{~F}$ & $\begin{array}{l}\text { Preterm, } \\
\text { gestosis }\end{array}$ & None & Yes & Birth & $3 \mathrm{mo}$. & 2 mg/kg/day & $18 \mathrm{mo}$ & 15 mo. & None & Steroids & None \\
\hline 26 & $\mathrm{~F}$ & None & Beard, tragus tongue, neck & Yes & Birth & $2 \mathrm{mo}$ & $\begin{array}{l}0.5-2 \\
\mathrm{mg} / \mathrm{kg} / \text { day }\end{array}$ & $18 \mathrm{mo.}$ & $16 \mathrm{mo.}$ & None & Steroids & None \\
\hline 27 & $\mathrm{~F}$ & None & None & Yes & $2 \mathrm{mo}$ & 4 mo. & $2 \mathrm{mg} / \mathrm{Kg} /$ day & $28 \mathrm{mo}$. & $14 \mathrm{mo.}$ & None & Steroids & None \\
\hline 28 & $\mathrm{~F}$ & None & $\begin{array}{l}\text { Beard, preauricular right, } \\
\text { lower lip, mucosal }\end{array}$ & Yes & $1 \mathrm{mo}$ & $2 \mathrm{mo}$ & $2 \mathrm{mg} / \mathrm{kg} / \mathrm{day}$ & $14 \mathrm{mo}$. & $12 \mathrm{mo}$. & None & Steroids & None \\
\hline 29 & M & None & None & Yes & $3 \mathrm{mo}$. & $5 \mathrm{mo}$ & $2 \mathrm{mg} / \mathrm{kg} / \mathrm{day}$ & $23 \mathrm{mo}$. & $18 \mathrm{mo}$ & None & Steroids & None \\
\hline 30 & $\mathrm{~F}$ & None & None & Yes & $1 \mathrm{mo}$. & $4 \mathrm{mo}$ & 2 mg/kg/day & $10 \mathrm{mo}$ & 6 mo. & None & None & None \\
\hline 31 & $\mathrm{~F}$ & None & Beard, lower lip, tragus right & Yes & $2 \mathrm{mo}$. & 2 mo. & 2 mg/kg/day & $25 \mathrm{mo.}$ & $23 \mathrm{mo.}$ & None & Steroids & None \\
\hline 32 & $\mathrm{~F}$ & None & None & Yes & $2 \mathrm{mo}$. & $4 \mathrm{mo}$. & 2 mg/kg/day & $17 \mathrm{mo}$. & $13 \mathrm{mo}$. & None & Steroids & None \\
\hline 33 & M & & None & Yes & - & $6 \mathrm{mo}$. & 2 mg/kg/day & $20 \mathrm{mo}$. & $14 \mathrm{mo.}$ & None & Steroids & None \\
\hline 34 & $\mathrm{~F}$ & None & Abdomen and foot & Yes & $1 \mathrm{mo}$. & $5 \mathrm{mo}$ & 2 mg/kg/day & 20 mo. & $15 \mathrm{mo}$. & None & Steroids & None \\
\hline 35 & M & Preterm & None & Yes & 2 mo. & 7 mo. & 2 mg/kg/day & 20 mo. & 13 mo. & None & Steroids & None \\
\hline 36 & $\mathrm{~F}$ & None & Beard, sternum, lower lip & Yes & $2 \mathrm{mo}$ & $3 \mathrm{mo}$ & 2 mg/kg/day & $17 \mathrm{mo.}$ & $14 \mathrm{mo.}$ & None & Steroids & None \\
\hline
\end{tabular}

CS, Cesarean section; d, days; M, male; F, female; mo, months. 
TABLE 2 | Endoscopic characteristics of the 36 patients.

\begin{tabular}{|c|c|c|c|c|c|}
\hline Case & $\begin{array}{l}\% \text { of obstruction } \\
\text { before therapy }\end{array}$ & $\begin{array}{l}\text { Pattern of } \\
\text { obstruction }\end{array}$ & $\begin{array}{l}\mathbf{N}^{\circ} \text { of airway } \\
\text { endoscopies }\end{array}$ & $\begin{array}{c}\% \text { of obstruction } \\
\text { after therapy }\end{array}$ & $\begin{array}{l}\text { Other airway's } \\
\text { localization }\end{array}$ \\
\hline 1 & $20 \%$ & Eccentric & 3 & $0 \%$ & Trachea \\
\hline 2 & $50 \%$ & Eccentric & 3 & $20 \%$ & None \\
\hline 3 & $50 \%$ & Eccentric & 5 & $10 \%$ & None \\
\hline 4 & $80 \%$ & Concentric & 4 & $0 \%$ & Pharynx \\
\hline 5 & $40 \%$ & Eccentric & 2 & $0 \%$ & Pharynx \\
\hline 6 & $40 \%$ & Concentric & 4 & ०\% & None \\
\hline 7 & - & - & 0 & - & None \\
\hline 8 & $80 \%$ & Concentric & 3 & - & None \\
\hline 9 & $50 \%$ & Eccentric & 3 & $10 \%$ & Pharynx \\
\hline 10 & $40 \%$ & Eccentric & 2 & $20 \%$ & Pharynx \\
\hline 11 & $70 \%$ & Eccentric & 7 & $0 \%$ & None \\
\hline 12 & $60 \%$ & Concentric & 3 & $0 \%$ & None \\
\hline 13 & $50 \%$ & Eccentric & 3 & $10 \%$ & None \\
\hline 14 & - & - & 0 & - & None \\
\hline 15 & $60 \%$ & Concentric & 5 & $0 \%$ & None \\
\hline 16 & $50 \%$ & Eccentric & 3 & $0 \%$ & None \\
\hline 17 & $50 \%$ & Concentric & 4 & $10 \%$ & None \\
\hline 18 & $10 \%$ & Eccentric & 1 & - & Pharynx \\
\hline 19 & $60 \%$ & Concentric & 2 & $10 \%$ & None \\
\hline 20 & $10 \%$ & Eccentric & 1 & - & None \\
\hline 21 & $70 \%$ & Eccentric & 2 & $20 \%$ & None \\
\hline 22 & $50 \%$ & Eccentric & 3 & $20 \%$ & None \\
\hline 23 & $20 \%$ & Eccentric & 2 & $0 \%$ & None \\
\hline 24 & $70 \%$ & Concentric & 2 & $10 \%$ & None \\
\hline 25 & $60 \%$ & Eccentric & 2 & $0 \%$ & Trachea \\
\hline 26 & $30 \%$ & Concentric & 2 & $10 \%$ & Pharynx \\
\hline 27 & $70 \%$ & Concentric & 2 & $10 \%$ & None \\
\hline 28 & $30 \%$ & Eccentric & 3 & $0 \%$ & Pharynx \\
\hline 29 & $50 \%$ & Eccentric & 5 & $10 \%$ & None \\
\hline 30 & $40 \%$ & Eccentric & 3 & $0 \%$ & None \\
\hline 31 & $40 \%$ & Concentric & 4 & $0 \%$ & Trachea \\
\hline 32 & $70 \%$ & Eccentric & 5 & $0 \%$ & None \\
\hline 33 & $60 \%$ & Eccentric & 3 & $30 \%$ & None \\
\hline 34 & $40 \%$ & Eccentric & 5 & $20 \%$ & None \\
\hline 35 & $70 \%$ & Eccentric & 3 & $0 \%$ & None \\
\hline 36 & $70 \%$ & Concentric & 1 & - & None \\
\hline
\end{tabular}

M, male; F, female.

discontinued as soon as propranolol is started. A prompt diagnosis and an early specific treatment are crucial to prevent hospitalization with repeated laryngoscopy, intubations, and prolonged steroid treatment, with known side effects and delay on vaccination calendar. Other imaging modalities such as magnetic resonance imaging (MRI) or computerized tomography (CT) should be reserved for cases with suspected PHACES syndrome, or to investigate differential diagnoses. In some cases, our patients underwent radiological evaluation by MRI, with very accurate results similar to the endoscopic findings for the head and neck $\mathrm{IH}$, except for the laryngeal manifestations, in particular the subglottic ones, for which the airway endoscopy is essential, both in confirming the diagnosis and the obstruction percentage $(7,11)$.

AIHs must be considered in cases of unexplained inspiratory stridor and/or dyspnea unresponsive to traditional treatment and recurrence. Stridor is a high-pitched sound, caused by total or subtotal upper airway obstruction. Biphasic stridor heard during both phases of respiration is typical of subglottic diseases. The subglottis includes the cricoid cartilage, which is prone to complications, being rigid and fixed. Differential diagnosis of subglottic obstruction includes inflammatory croup, reflux, subglottic obstruction, intubation granuloma, cysts, congenital cricoid malformation, foreign body, and infantile hemangioma 
(13). The specific timing of presentation of the IHs is very indicative and the endoscopic evaluation is crucial. Patients could be misdiagnosed as presentation is similar and other conditions improve with steroid therapy, both by inhalation and systemic delivery. Therefore, recurrence and worsening of respiratory symptoms despite therapies are suspicious for $\mathrm{IH}$.

In our retrospective study, we present data about the management of AIHs in 36 patients successfully treated with oral propranolol (Table 1). The median length of treatment was 15 months, which is consistent with data in the literature $(12,14)$. In our patients, therapy was discontinued at months 10 to 54 of age (average 20 and median 19), in keeping with previous case series (12). Based on our experience, we suggest starting oral propranolol as soon as possible, even before 5 weeks of age (15), and to stop it at least at 18 months of age, if started promptly or after 15 months of duration in cases in which the treatment is started after 3 months of age. Treatment efficacy and safety monitoring could be based on symptoms and vital parameters, reserving endoscopy only for diagnosis and at the end of treatment.

Some authors suggest dose-tapering of oral propranolol, while recent guidelines and also our personal experience confirm that it should be interrupted abruptly (1). Elluru et al. reported that six patients required additional medical or surgical approach for persistent respiratory symptoms, but none of our patients presented stridor after the first 1-2 weeks of treatment. In our case series, additional steroids therapy was employed in 10 patients, mainly in severe cases, while awaiting the initiation of propranolol therapy and discontinued afterward. In addition, we did not have propranolol non-responder in our cohort (14). However, different authors reported variable percentages of failure-cases, ranging from 9 to $22 \%(12,14,16)$. In our opinion these percentages are over-represented, might be due to delay of diagnosis and therapy start, duration of treatment, and age at discontinuation $(17,18)$.

Relapses occurred in five patients (13.9\%), due to (i) delay of treatment onset, (ii) wide extension of the cutaneous $\mathrm{IH}$, (iii) association with deep component of the skin lesion, (iv) involvement of the parotid gland, and (v) reduced duration of treatment. Interestingly, in three out of these five children, oral propranolol was administered at the dosage of $3 \mathrm{mg} / \mathrm{kg} / \mathrm{day}$. Moreover, AIH recurred only in two out of 28 patients on 2 $\mathrm{mg} / \mathrm{kg} /$ day regimen, thus in our opinion, relapses might not be due to dosage. Percentage of relapses in our population is consistent with literature data (12). Causes of relapses are still debated, indeed recurrences in our patients frequently occurred both in early therapy commencement (4/5) and in longer duration (3/5). For this reason, a clinical follow-up after treatment discontinuation is mandatory.

Only two out of 10 patients with large segmental $\mathrm{IH}$ of the face were diagnosed with PHACES syndrome compared to a higher percentage in literature data $(47 \%)(4,6)$. When PHACES syndrome is suspected, it is necessary to perform a full workup, including cardiologic, ophthalmologic, and neurologic investigation with appropriate imaging (19). Meanwhile, in the case of suspected PHACES with severe airway obstruction, treatment should be started at the lowest dose, divided in some cases in three administration, in order to prevent stroke occurrence (20), then adjusted based on the finding of MRI on cerebro-vascular anomalies (21). In our patients, the same plan was adopted for severe preterm babies. Several protocols for the management of AIHs have been proposed in the literature, but none has been standardized thus far $(14,22,23)$. Over the years, our experience in the diagnostic, treatment, and follow-up indications has improved. When propranolol therapy was first introduced, our approach was more invasive, with several and close endoscopic procedures during treatment. We also observed that the trend of this pathology is systematic and therefore we believe that endoscopy does not have to be repeated during treatment, but it should be performed 1 month after discontinuation of propranolol to evaluate the results and possible recurrence of $\mathrm{AIH}$, avoiding general anesthesia and controlling public health-care costs. Of course, further endoscopic evaluation should be carried out in case of relapse of respiratory symptoms and therefore persistence of $\mathrm{AIH}$, with the need to continue the pharmacological treatment. In our experience, finding of residual disease with obstruction of the respiratory space up to $20 \%$ does not contraindicate the end of the therapy.

The limitations of this study are: (i) it is retrospective, (ii) a reduced number of cases, and (iii) unexplained relapses causes in a limited number of patients.

In conclusion, the diagnosis of AIH should be suspected in cases of biphasic stridor and/or typical cutaneous involvement, and always confirmed with airway endoscopy. Oral propranolol is the mainstay of therapy and should not be preceded by oral steroid, due to its rapid efficacy. Treatment should be started as soon as possible with a duration for at least 15 months and/or reaching 18 months of patient age. Clinical follow-up after discontinuation of therapy is mandatory to promptly manage possible relapses.

\section{DATA AVAILABILITY STATEMENT}

The original contributions presented in the study are included in the article/supplementary material, further inquiries can be directed to the corresponding author.

\section{AUTHOR CONTRIBUTIONS}

All authors listed have made a substantial, direct, and intellectual contribution to the work and approved it for publication.

\section{ACKNOWLEDGMENTS}

We would like to thank our patients and their families for accepting to participate to share their data in this manuscript. 


\section{REFERENCES}

1. Hodak A, Pate BM, Pelletier JL, Sandrock D, Weinberg ST, Whelan MA, et al. Clinical practice guideline for the management of infantile hemangiomas. Pediatrics. (2019) 143:e20183475. doi: 10.1542/peds.2018-3475

2. Haggstrom AN, Lammer EJ, Schneider RA, Marcucio R, Frieden IJ. Patterns of infantile hemangiomas: new clues to hemangioma pathogenesis and embryonic facial development. Pediatrics. (2006) 117:698-703. doi: 10.1542/peds.2005-1092

3. Uthurriague $\mathrm{C}$, Boccara $\mathrm{O}$, Catteau $\mathrm{B}$, Fayoux P, Léauté-Labrèze $\mathrm{C}$, Chiaverini $\mathrm{C}$, et al. Skin patterns associated with upper airway infantile haemangiomas: a retrospective multicentre study. Acta Derm Venereol. (2016) 96:96316. doi: 10.2340/00015555-2357

4. Haggstrom AN, Skillman S, Garzon MC, Drolet BA, Holland K, Matt B. et al. Clinical spectrum and risk of PHACE syndrome in cutaneous and airway hemangiomas. Arch Otolaryngol Head Neck Surg. (2011) 137:68017. doi: 10.1001/archoto.2011.113

5. Metry DW, Haggstrom AN, Drolet BA, Baselga E, Chamlin S, Garzon M, et al. A prospective study of PHACE syndrome in infantile hemangiomas: demographic features, clinical findings, and complications. Am J Med Genet. (2006) 140 A:975-86. doi: 10.1002/ajmg.a.31189

6. Czechowicz JA, Benjamin T, Bly RA, Ganti SN, Balkin DM, Perkins JA, et al. Airway hemangiomas in PHACE syndrome: a multicenter experience. Otolaryngol Head Neck Surg. (2020) 165:182-6. doi: 10.1177/0194599820966622

7. Monnier P. Pediatric Airway Surgery: Management of Laryngotracheal Stenosis in Infants and Children. Berlin, Heidelberg: Springer (2011).

8. Rahbar R, Nicollas R, Roger G, Triglia JM, Garabedian EN, McGill TJ, et al. The biology and management of subglottic hemangioma; past, present, future. Laryngoscope. (2004) 114:1880-91. doi: 10.1097/01.mlg.0000147915.58862.27

9. Bitar MA, Moukarbel RV, Zalzal, GH. Management of congenital subglottic hemangioma: trends and success over the past 17 years. Otolaryngol Head Neck Surg. (2005) 132:226-31. doi: 10.1016/j.otohns.2004.09.136

10. O-Lee TJ, Messner A. Subglottic Hemangioma. Otolaryngol Clin North Am. (2008) 41:903-11. doi: 10.1016/j.otc.2008.04.009

11. Myer CM, O'connor DM, Cotton RT. Proposed grading system for subglottic stenosis based on endotracheal tube sizes. Ann Otol Rhinol Laryngol. (1994) 103:319-23. doi: 10.1177/000348949410300410

12. Broeks IJ, Hermans DJJ, Dassel ACM, Van der Vleuten CJM, Van Beynum IM. Propranolol treatment in life-threatening airway hemangiomas: a case series and review of literature. Int J Pediatr Otorhinolaryngol. (2013) 77:1791800. doi: 10.1016/j.ijporl.2013.08.011

13. Ida JB, Thompson DM. Pediatric stridor. Otolaryngol Clin North Am. (2014) 47:795-819. doi: 10.1016/j.otc.2014.06.005

14. Elluru RG, Friess MR, Richter GT, Grimmer JF, Darrow DH, Shin JJ, et al. Multicenter evaluation of the effectiveness of systemic propranolol in the treatment of airway hemangiomas. Otolaryngol Head Neck Surg (United States). (2015) 153:452-60. doi: 10.1177/01945998155 91809

15. El Hachem M, Gesualdo F, Diociaiuti A, Berti I, Vercellino N, Boccaletti V, et al. Safety and effectiveness of oral propranolol for infantile hemangiomas started before 5 weeks and after 5 months of age: an Italian multicenter experience. Ital J Pediatr. (2017) 43:40. doi: 10.1186/s13052-017-0357-9

16. Drolet BA, Frommelt PC, Chamlin SL, Haggstrom A, Bauman NM, Chiu YE, et al. Initiation and use of propranolol for infantile hemangioma: report of a consensus conference. Pediatrics. (2013) 131:128-40. doi: 10.1542/peds.2012-1691

17. Liu Z, Yeo YH, Jackson C, Trimble, K. Treatment failure with propranolol for subglottic haemangioma. BMJ Case Rep. (2019) 12:e227135. doi: 10.1136/bcr-2018-227135

18. Phillips RJ, Lokmic Z, Crock CM, Penington A. Infantile haemangiomas that failed treatment with propranolol: clinical and histopathological features $J$ Paediatr Child Health. (2014) 50:619-25. doi: 10.1111/jpc.12600

19. Garzon MC, Epstein LG, Heyer GL, Frommelt PC, Orbach DB, Baylis AL, et al. PHACE syndrome: consensus-derived diagnosis and care recommendations. J Pediatr. (2016) 178:24-33e2. doi: 10.1016/j.jpeds.2016.07.054

20. Metry D, Frieden IJ, Hess C, Siegel D, Maheshwari M, Baselga E, et al. Propranolol use in PHACE syndrome with cervical and intracranial arterial anomalies: collective experience in 32 infants. Pediatr Dermatol. (2013) 30:7189. doi: 10.1111/j.1525-1470.2012.01879.x

21. Léauté-Labrèze C, Harper JI, Hoeger PH. Infantile haemangioma. Lancet. (2017) 390:85-94. doi: 10.1016/S0140-6736(16)00645-0

22. Perkins JA, Chen EY, Hoffer FA, Manning, SC. Proposal for staging airway hemangiomas. Otolaryngol Head Neck Surg. (2009) 141:51621. doi: 10.1016/j.otohns.2009.06.751

23. Balakrishnan K, Perkins JA. Management of airway hemangiomas. Expert Rev Respir Med. (2010) 4:455-62. doi: 10.1586/ers.10.46

Conflict of Interest: Two of the authors ME and AD of this publication are members of the European Reference Network ERN-SKIN and of Vascular Anomalies Working Group VASCA WG of the ERN for rare Multisystemic Vascular Diseases VASCERN.

The remaining authors declare that the research was conducted in the absence of any commercial or financial relationships that could be construed as a potential conflict of interest.

Publisher's Note: All claims expressed in this article are solely those of the authors and do not necessarily represent those of their affiliated organizations, or those of the publisher, the editors and the reviewers. Any product that may be evaluated in this article, or claim that may be made by its manufacturer, is not guaranteed or endorsed by the publisher.

Copyright (c) 2021 Corbeddu, Meucci, Diociaiuti, Giancristoforo, Rotunno, Gonfiantini, Trozzi, Bottero and El Hachem. This is an open-access article distributed under the terms of the Creative Commons Attribution License (CC BY). The use, distribution or reproduction in other forums is permitted, provided the original author(s) and the copyright owner(s) are credited and that the original publication in this journal is cited, in accordance with accepted academic practice. No use, distribution or reproduction is permitted which does not comply with these terms. 